\title{
THE 2007 INTERNATIONAL LIBRARY SURVEY IN LATIN AMERICA AND THE CARIBBEAN
}

\author{
Claude Akpabie, UNESCO Institute for Statistics
}

\begin{abstract}
This paper summarises the results of the 2007 UNESCO Institute for Statistics/ IFLA/ISO library survey which was conducted across Latin America and the Caribbean.

UIS is a founder member of the Partnership for the Measurement of ICTs for Development the official international body responsible for the statistical aspects of the follow up to the World Summit on the Information Society. The priority for the culture team at the Institute is the revision of the 1986 UNESCO framework for cultural statistics, while in communications the team is working on international statistics for the use of ICTs in Education, and information literacy.

The 2007 library survey has collected statistics on libraries in each of the Latin American subregions; Central America, Caribbean, South America. The questionnaire covered both public libraries and higher education libraries but most responses concerned public libraries only. A mixed response was obtained to 'new topics' such as; internet connections, e-books, and database access.

The papers discusses the lessons learnt from the survey, including where response rates or definitions might be improved as well as areas where there is simply a lack of data. The potential for an international survey of library statistics will be revisited, as well as consideration of the minimum statistical reporting requirement for a functioning national library system.
\end{abstract}

\section{INTRODUCTION}

In January 2006, the International Federation of Library Associations (IFLA), the International Standards Organisation (ISO) Library Statistics Committee and the UNESCO Institute for Statistics (UIS) agreed to explore the possibility of reviving the UNESCO global survey which took place regularly until 1999 when it was discontinued due to issues with data quality and coverage.

The revised survey was conducted according to current international standards, making particular use of the new ISO 2789 statistical standard for libraries. Latin America and the Caribbean were chosen as a pilot region based on an initial review of contacts conducted by IFLA.

The new survey questionnaire was developed by the UIS with extensive input from IFLA and ISO experts. It was launched in mid-2007 in 41 Latin American and Caribbean countries. Data entry, data cleaning and processing of the pilot survey responses were completed by the UIS with the help of an intern from the 
École de bibliothéconomie et des sciences de l'information (EBSI)-Université de Montréal who undertook a preliminary analytical review of the survey returns as a research project. Discussion between the partners led to the identification of 22 core statistical indicators to adequately map the status and trends in the library sector. In addition to IFLA and UIS support, the UNESCO Communication and Information Sector funded the implementation of the survey.

\section{LEVEL OF RESPONSE TO THE SURVEY}

Of the 41 countries surveyed in Latin America and the Caribbean, 26 (including a nil response from Bolivia) returned completed questionnaires (as shown in Figure 1), making the response rate $63 \%$. Such a response rate is not unusual for a new international survey as national authorities may not currently be collecting data in the area under study.

The pattern of responses to individual questions showed considerable variation:

- Data was more readily available for public libraries than for libraries at institutions for higher education. Only 14 countries of 25 with valid data reported the number of higher education libraries, while all of them provided information on the number of public libraries. This may indicate that data on public and higher education libraries are not necessarily collected or centralised by a single organisation.

- Data were more available for 'traditional statistics' (e.g. volumes, seats, internet access and websites services, registered users, loans, headcount of library employees), rather than for items, such as e-resources, visits, events, opening hours, full-time-equivalent library employees and expenditures. The items had scarce data either because they needed more clarification of their definition at the international level, thus requiring more intensive data collection, or because they were not previously included in international surveys.

Only 9 out of 25 countries provided the most commonly available indicator for higher education libraries - the average number of employees - whereas a much wider range of indicators were available for public libraries (see Figure 2). The highest response rates were for numbers of public libraries per 1000 inhabitants or literate people, average number of employees in public libraries, ratio of female to male employees, percentage of public libraries with internet access for users, and volumes, registered users or loans per 1000 inhabitants.

\section{MAJOR OBSERVATIONS}

The following section highlights some of the results from the survey. 


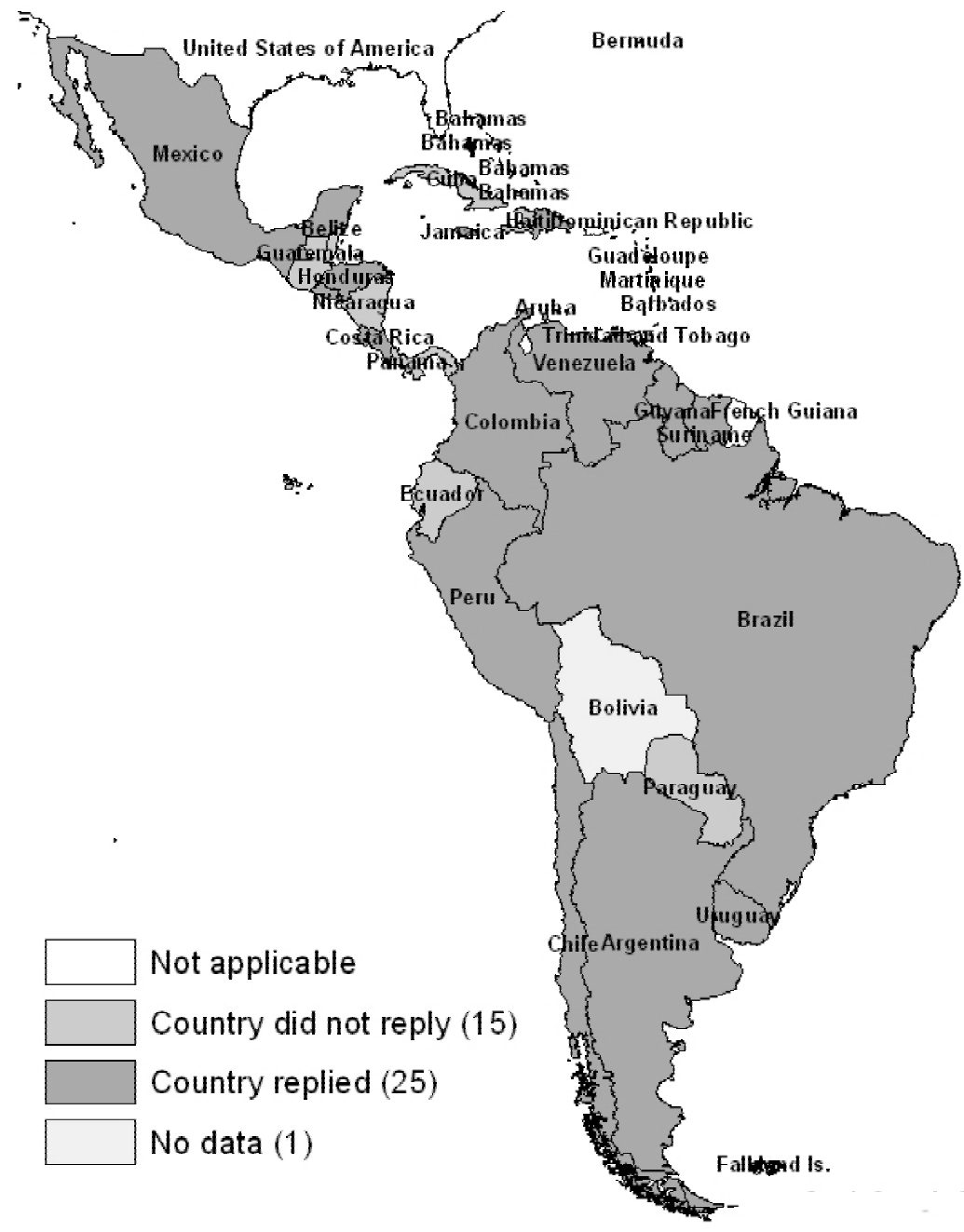

Figure 1. Responses by country to the library survey in Latin America and the Caribbean (Source: UNESCO Institute for Statistics, August 2008)

\section{Public library access}

Figure 3 below illustrates that Jamaica (23), Saint Vincent and Grenadines (17), Saint Lucia (11), Bahamas (10) and Mexico (7) have higher numbers of libraries for every 100,000 inhabitants. For every 100,000 literate adults this number rises to $33,23,15,13$ and 10 respectively for the same countries. Within this group, Mexico could be considered to offer a 'more balanced' provision of library services to its citizens if the population size is taken into consideration. Yet with the 


\section{Percentage of each indicator availability for all countries}

Number of visits in public libraries per 1000 literate inhabitants

Average number of loans per 1000 literate inhabitants in public libraries

Average number of volumes in public libraries per 1000 literate inhabitants

Number of visits in higher education institution libraries per students of higher education

Expenditure on literature and information per student

of higher education in higher education institution

Ratio of female to male employees in higher education institutions libraries

Expenditure on literature and information per capita in public libraries (in PPPUS\$)

Average number of loans per student (higher education) in higher education institution libraries

Number of registered users in higher education libraries as a percentage of number of students

Average number of volumes in higher education institution library per 1000 students of higher

Number of visits in public libraries per 1000 inhabitants

Average number of employees in higher education institution libraries

Percentage of public libraries offering websites

Number of registered users per 1000 literate inhabitants in public libraries

Ratio of female to male employees in public libraries

Average number of loans per 1000 inhabitants in public libraries

Number of registered users per 1000 inhabitants in public libraries

Average number of volumes in public libraries per 1000 inhabitants

Average number of public libraries per 1000 literate population

Percentage of public libraries offering an internet access for users

Average number of public libraries per 1000 inhabitants

Average number of employees in public libraries

Number of public libraries

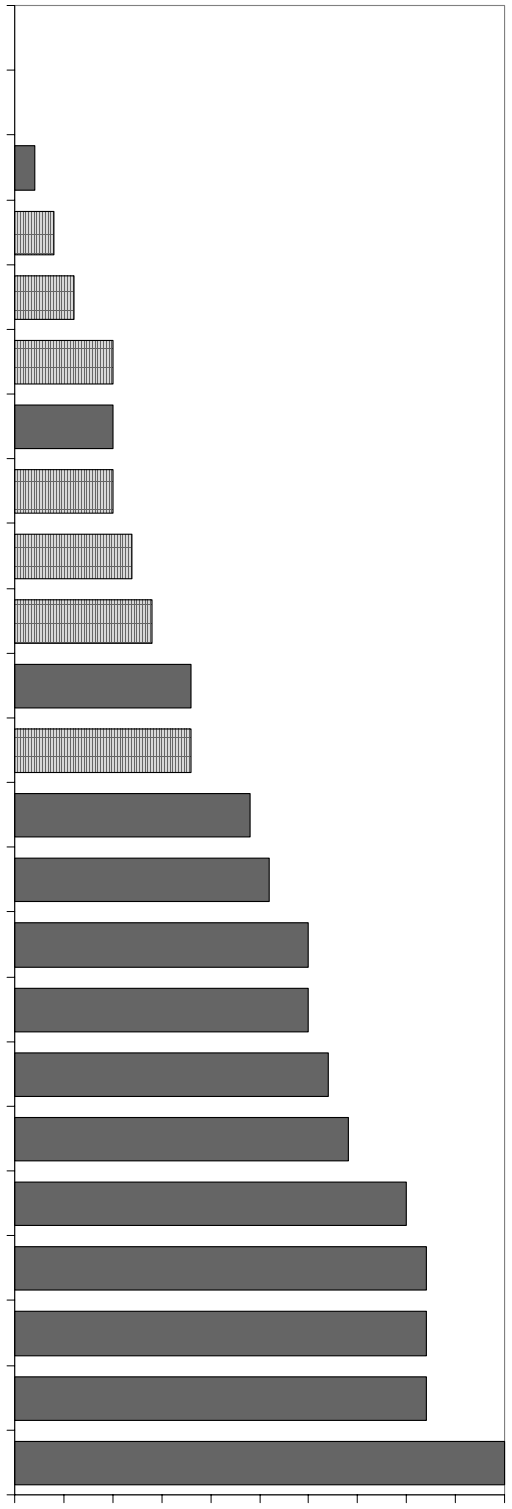

$\begin{array}{lllllllllll}0 & 0.1 & 0.2 & 0.3 & 0.4 & 0.5 & 0.6 & 0.7 & 0.8 & 0.9 & 1\end{array}$

Higher education library

Public library

Figure 2. Level of responses listed by core indicator (Source: UIS August 2008) 
exception of Mexico, the seemingly positive outlook reported by the other countries appears to reflect their small populations, which, in total, fall below $1 \%$ of the overall sample of respondent country populations. It is therefore difficult to draw a clear-cut conclusion about the adequacy of library services in these countries. Data for Argentina, Chile and the Netherlands Antilles reveal only a partial picture.

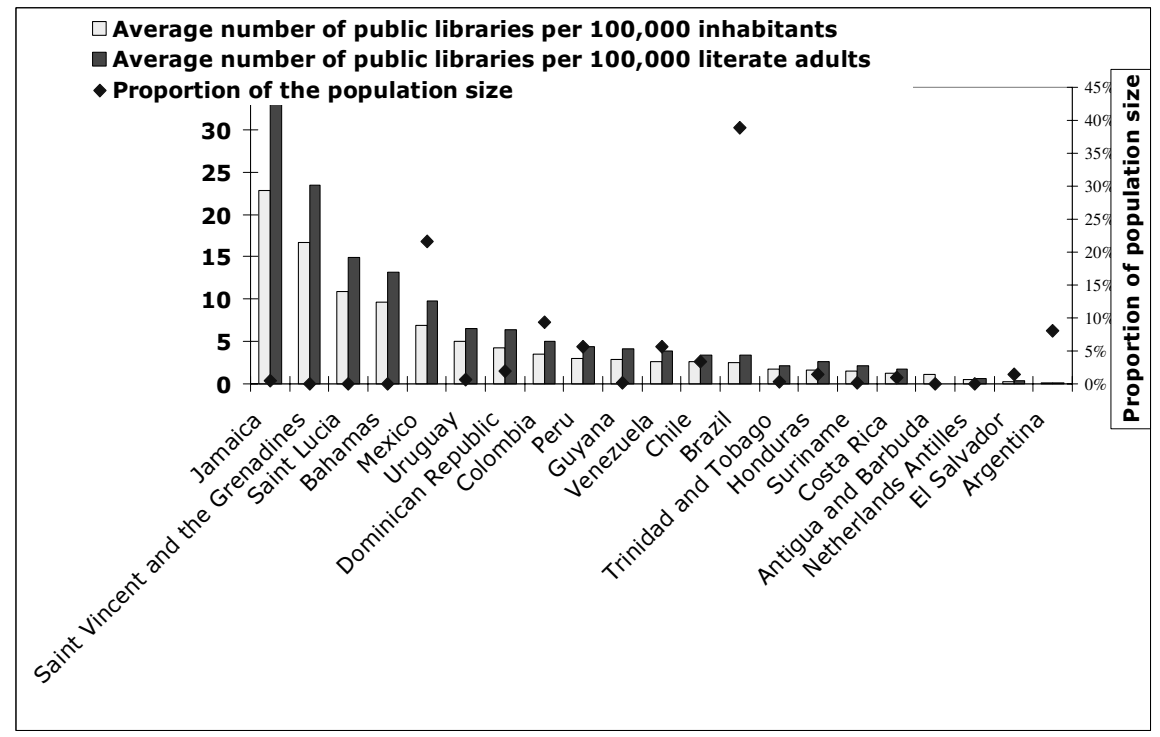

Figure 3. Number of public libraries per 100,000 inhabitants and literate adults (Source: UIS August 2008)

Even allowing for its large population size influence, Brazil presented a much lower number of public libraries per 100,000 inhabitants or adult literate, which suggests a potential coverage issue. Countries with higher levels of literacy have a smaller gap between the two indicators - number of public libraries related respectively to the total population or the number of literate adults

\section{Collections and internet services}

The number of volumes of public libraries ranged from 12 for every 1000 inhabitants in El Salvador to almost 600 per 1000 inhabitants in Saint Lucia (Figure 4.). The higher figures for this indicator may be misleading as most of them are from Caribbean islands with comparatively few public libraries that contain arguably modest collections only suitable for their relatively small population size. Saint Vincent and the Grenadines, which is not displayed in Figure 4, shows an exceptional 2497 number of volumes in public libraries per 1000 inhabitants. These figures are of course overall national aggregates and actual supply or accessibility of libraries will depend on local availability with urban populations often having easier 
access than remote rural communities. When the total number of volumes in public library are related to the overall number of literate adults, the indicator rises significantly in several countries reflecting a closer relationship between the supply of books and a skilled readership.

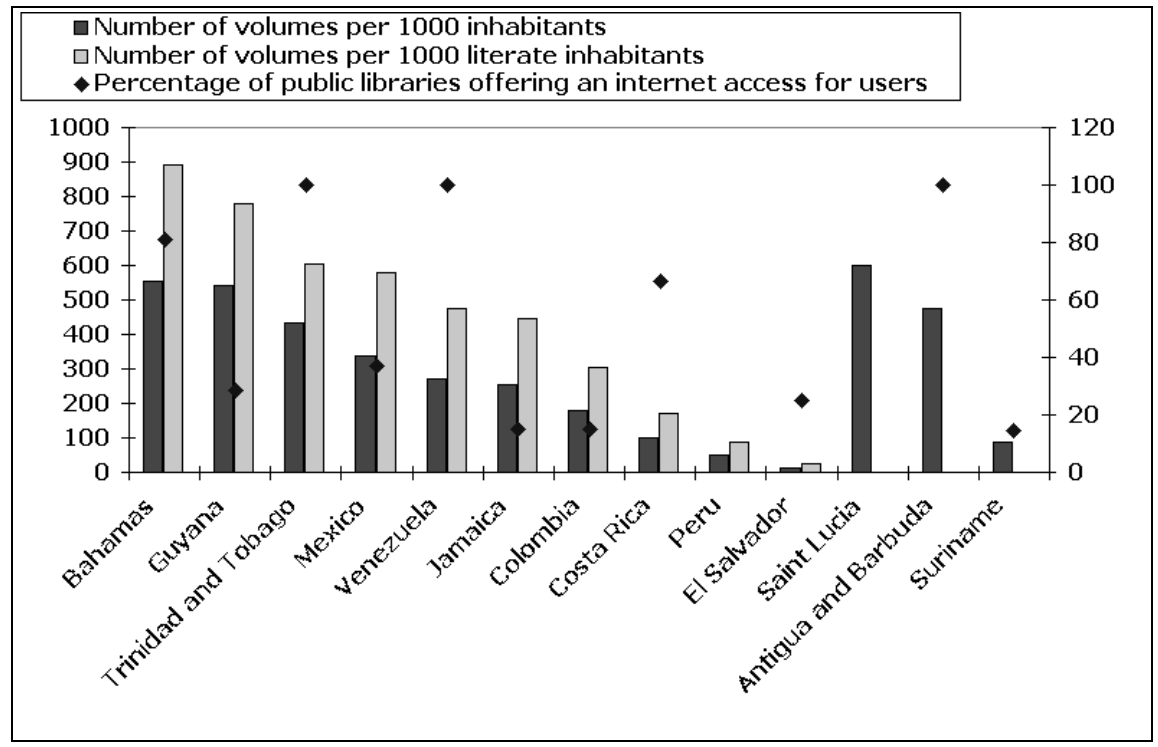

Figure 4. Number of volumes per 1000 inhabitants and literate adults in public libraries. Internet access in public libraries (Source: UIS August 2008)

As far as internet services are concerned, 21 countries (NB: not all are displayed on the graph in Figure 4) reported that their public libraries allowed users to access the internet. Six countries reported that all their public libraries provided this service while four others reported that at least $50 \%$ did so. Twelve countries reported data on public libraries with their own websites. Only two countries (Antigua and Barbuda, and the Netherlands Antilles ${ }^{1}$ reported that all their libraries have websites. In Argentina ${ }^{2} 59.1 \%$ of libraries had websites while this figure was by far marginal in the other countries, notably Venezuela (0.13), Chile (1.4), Columbia (2.0), Bahamas (9.4) and Jamaica (14.8). Questions on the availability of ebooks and other e-resources resulted in even lower response rates.

\section{Readers and usage}

While excluding Argentina whose data are partial, the number of registered users ranged from 2 per 1000 people in Suriname to more than 200 per 1000 people in Jamaica (234) and Guyana (254). A different perspective emerges when consider-

\footnotetext{
Data refer to Saint Maartens only

2 Data do not include libraries from Buenos Aires
} 
ing the size of the literate population. The overall level of registered users increases for the majority of countries but no country had registered users tallying more than $50 \%$ of the population. Given the small size of indicator sample, it is difficult to ascertain a clear positive relationship between the number of loans and number of registered users per 1000 inhabitants. When low numbers of registered users correspond to a relatively high level of loans per one 1000 inhabitants, it may be suggestive of a small number of people taking out a large number of books or a somewhat smaller number of loans rotated across a larger group of people not necessarily registered. In addition, Jamaica and Argentina have explicitly stated that their loan statistics include renewals and that their data may potentially include inter-library loans.

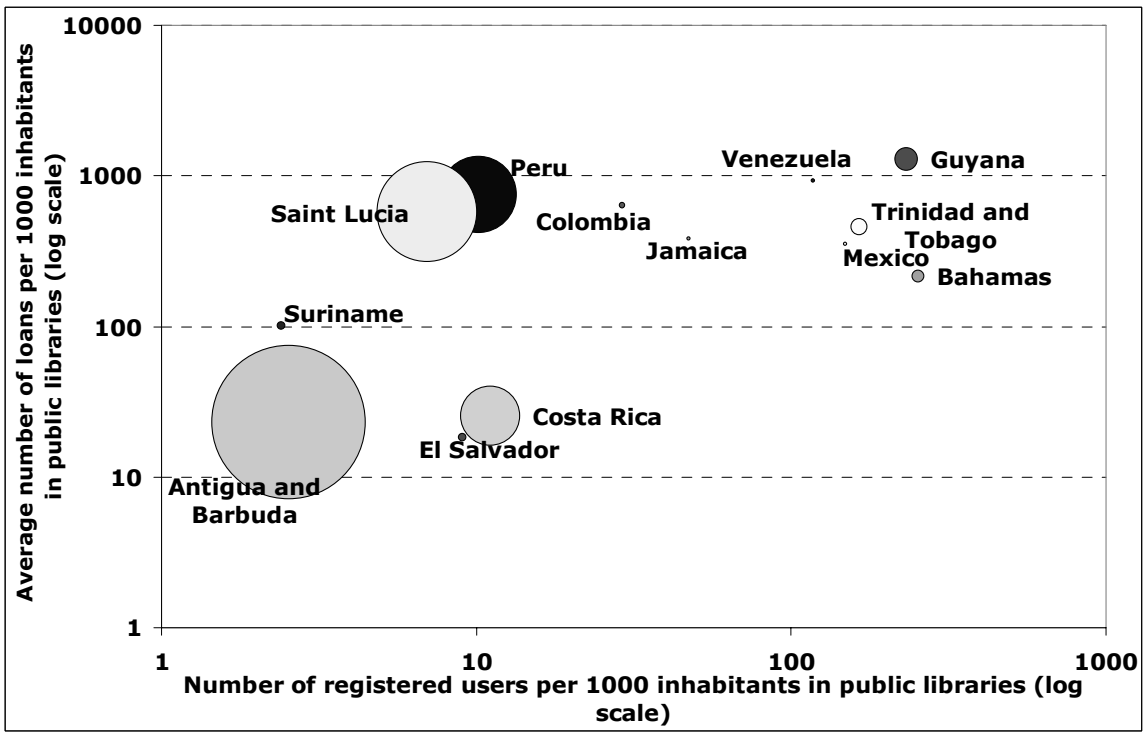

Figure 5. Registered users and loans per 1000 inhabitants (circle size corresponds to population size) (Source: UIS August 2008)

A further complicating factor is library opening hours. Guyana and Jamaica reported that $80 \%$ of their public libraries opened for less than 24 hours a week. In contrast, both countries have high levels of loans and registered users per 1000 inhabitants despite their small populations (as reflected by the size of the circles in Figure 5). Therefore, the shorter opening hours do not appear to hamper accessibility to libraries - perhaps because libraries are located close to readers or can be reached quickly. Chile, St Kitts and Nevis, Suriname and Venezuela reported that all their public libraries stayed open for over 40 hours a week. Figure 5 indicates that long opening hours do not always translate to large numbers of loans and registered users. Other social, cultural and personal habits may also play a part. 


\section{Employment}

The average number of people employed per library ranged from less than 2 in Chile, Mexico and Jamaica, to 17 in Antigua and Barbuda. As shown in Figure 6, unlike other sectors of employment, women seem to be dominating the workforce $\mathrm{n}$ libraries with more than twice as many of them compared to men in all countries except Argentina, Chile and Costa Rica.

The ratio of employees to registered users can be utilised as a proxy measure of the workload per employee. In El Salvador, there were almost 5000 registered users per employee. Yet in Suriname where there was an average of 8 employees per library, there was a more modest 18 registered users per employee.

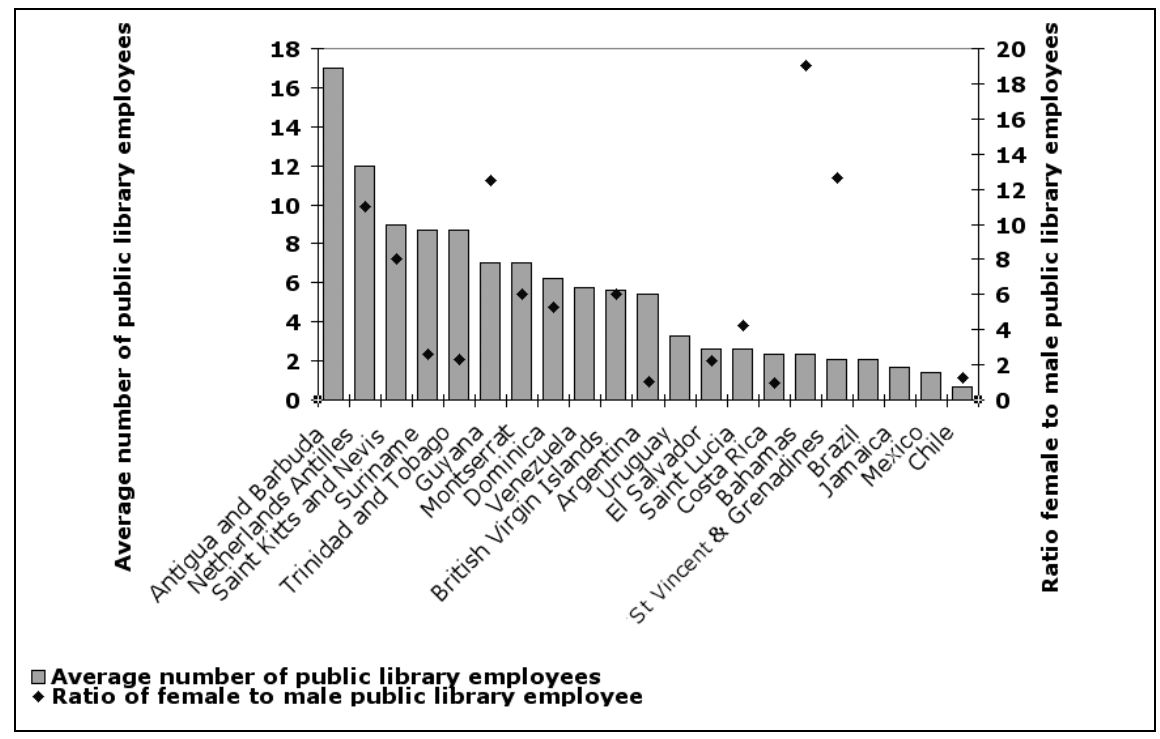

Figure 6. Employment in libraries \& female participation (Source: UIS August 2008)

\section{CONCLUSIONS}

The 2007 international library survey provides an overall picture of both the availability of library statistics and the very different levels of library provision in Latin American and Caribbean countries. It has also demonstrated that there is no uniform relationship between overall stock of books, length of opening hours and numbers of users.

At the same time, it must be stressed that the survey represents a 'pilot' test of new definitions and standards. Hopefully, the survey will spark international discussions on library indicators to determine best practices for their selection and interpretation. 
The pilot survey results have highlighted similar constraints encountered in previous UNESCO surveys:

- lack of co-ordination between institutions, which makes it difficult to collect complete data on all libraries within a country

- a need for improved clarity in data definitions and their application at the national level

- low coverage for several key variables (e-resources, visits, events, opening hours, full-time-equivalent library employees and expenditures)

Such problems raise the pressing question of how best to determine the minimum dataset needed to run a library or a national library system in transitional and developing countries with vastly varied institutional structures. The results presented here stress the importance of librarians in developing countries. They also highlight the need to use literacy data to identify areas where libraries are more likely to find an easy readership or conversely, where they might play an important role in combating illiteracy.

The data gaps also suggest the need to strengthen the culture of data collection in library systems at the national level. Countries might consider undertaking a systematic and gradual approach to mapping data sources in addition to refining definitions and collection methodologies for capacity building purposes.

It is a fervent hope that other regions will be able to follow the example of Latin America and the Caribbean, and that all countries will develop library statistics to the point where consistent coverage is achieved. This will support the library sector's ability to fight illiteracy, promote access to information and foster the growth of knowledge in societies. This should be validated within the countries concerned as well as in the international arena. 


\section{ANNEX: AVAILABILITY OF THE CORE INDICATORS BY COUNTRY}

Note: HE= Higher Education; PPPUS\$ = Purchasing Power Parity US\$

\begin{tabular}{|c|c|c|c|c|c|c|c|c|}
\hline$\stackrel{\vec{E}}{\vec{E}}$ & 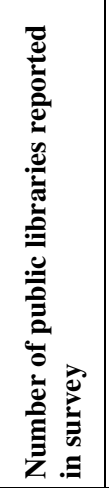 & 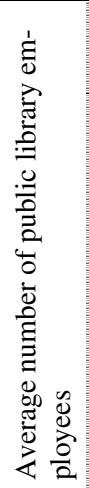 & 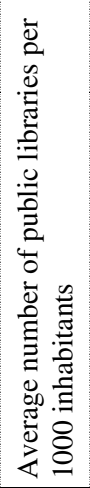 & 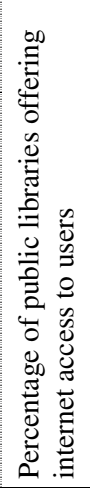 & 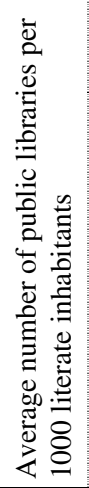 & 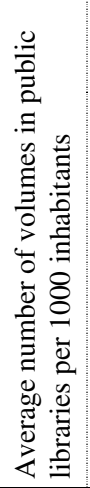 & 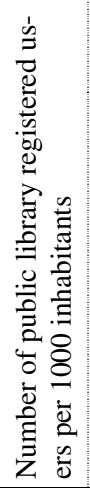 & 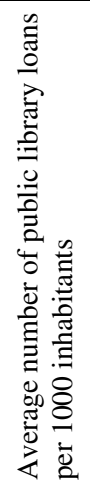 \\
\hline Antigua and Barbuda & 1 & 17 & 0.012 & 100.0 & $\ldots$ & 474 & 47.4 & 379.7 \\
\hline Argentina & 27 & 5 & 0.001 & 51.9 & 0.001 & 8 & 0.6 & 5.5 \\
\hline Bahamas & 32 & 2 & 0.097 & 81.3 & 0.132 & 555 & 9.1 & 18.3 \\
\hline Brazil & 4801 & 2 & 0.025 & 9.3 & 0.034 & $\ldots$ & $\ldots$ & $\ldots$ \\
\hline British Virgin Islands & 5 & 6 & $\ldots$ & 40.0 & $\ldots$ & $\ldots$ & $\ldots$ & $\ldots$ \\
\hline Chile & 428 & 1 & 0.026 & 2.3 & 0.034 & 18 & 11.1 & 25.2 \\
\hline Colombia & 1595 & $\ldots$ & 0.035 & 15.2 & 0.050 & 179 & 7.0 & 576.8 \\
\hline Costa Rica & 57 & 2 & 0.013 & 66.7 & 0.018 & 101 & $\ldots$ & 116.2 \\
\hline Dominica & 4 & 6 & & 50.0 & $\ldots$ & $\ldots$ & $\ldots$ & $\ldots$ \\
\hline Dominican Republic & 398 & $\ldots$ & 0.043 & $\ldots$ & 0.064 & $\ldots$ & 85.2 & $\ldots$ \\
\hline El Salvador & 16 & 3 & 0.002 & 25.0 & 0.004 & 12 & 29.2 & $\ldots$ \\
\hline Guyana & 21 & 7 & 0.028 & 28.6 & 0.041 & 541 & 253.8 & 215.3 \\
\hline Honduras & 116 & $\ldots$ & 0.016 & 6.9 & 0.027 & $\ldots$ & $\ldots$ & $\ldots$ \\
\hline Jamaica & 615 & 2 & 0.228 & 14.8 & 0.332 & 254 & 233.5 & 1277.1 \\
\hline Mexico & 7210 & 1 & 0.068 & 37.1 & 0.098 & 338 & 2.5 & 23.0 \\
\hline Montserrat & 1 & 7 & $\cdots$ & 100.0 & $\cdots$ & $\ldots$ & $\ldots$ & $\ldots$ \\
\hline Netherlands Antilles & 1 & 12 & 0.005 & 100.0 & 0.007 & 344 & 29.1 & 635.5 \\
\hline Peru & 826 & $\ldots$ & 0.030 & $\ldots$ & 0.044 & 48 & $\ldots$ & $\ldots$ \\
\hline Saint Kitts and Nevis & 3 & 9 & & 100.0 & & & & \\
\hline Saint Lucia & 18 & 3 & 0.109 & $\ldots$ & 0.150 & 598 & 148.8 & 350.1 \\
\hline $\begin{array}{l}\text { Saint Vincent } \\
\text { and the Grenadines }\end{array}$ & 20 & 2 & 0.167 & $\cdots$ & 0.235 & 2497 & 118.0 & 927.5 \\
\hline Suriname & 7 & 9 & 0.015 & 14.3 & 0.022 & 87 & 2.4 & 101.3 \\
\hline Trinidad and Tobago & 23 & 9 & 0.017 & 100.0 & 0.022 & 435 & 164.4 & 457.5 \\
\hline Uruguay & 167 & 3 & 0.050 & 19.2 & 0.066 & $\ldots$ & $\ldots$ & \\
\hline Venezuela & 728 & 6 & 0.027 & 100.0 & 0.039 & 269 & 10.2 & 752.9 \\
\hline $\begin{array}{l}\text { Percentage of each indicator } \\
\text { Availability for all countries }\end{array}$ & $100.0 \%$ & $84.0 \%$ & $84.0 \%$ & $84.0 \%$ & $80.0 \%$ & $68.0 \%$ & $64.0 \%$ & $60.0 \%$ \\
\hline
\end{tabular}




\begin{tabular}{|c|c|c|c|c|c|c|c|c|}
\hline 总 & 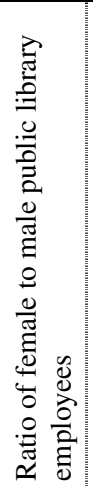 & 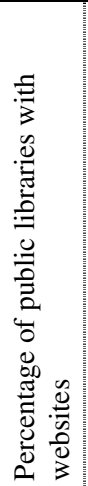 & 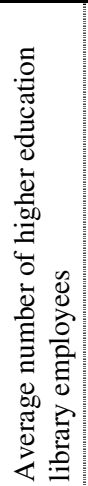 & 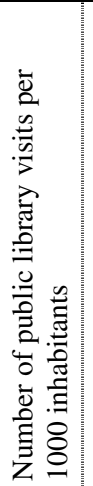 & 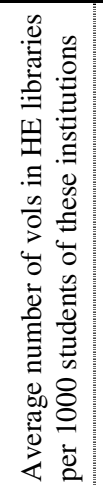 & 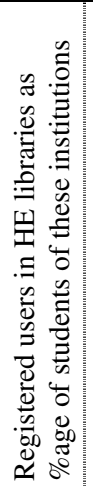 & 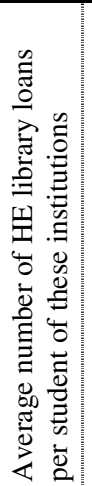 & 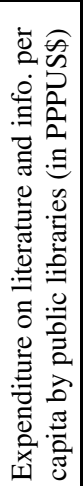 \\
\hline Antigua and Barbuda & $\ldots$ & 100.0 & $\ldots$ & $\ldots$ & $\ldots$ & $\ldots$ & $\ldots$ & $\ldots$ \\
\hline Argentina & 1.06 & 51.9 & $\ldots$ & 11.1 & $\ldots$ & $\ldots$ & $\ldots$ & $\ldots$ \\
\hline Bahamas & 19.00 & 9.4 & 3.1 & $\ldots$ & 3157.5 & $\ldots$ & $\ldots$ & 0.92 \\
\hline Brazil & $\ldots$ & $\ldots$ & $\ldots$ & $\ldots$ & $\ldots$ & $\ldots$ & $\ldots$ & $\ldots$ \\
\hline British Virgin Islands & 6.00 & 20.0 & $\ldots$ & $\ldots$ & $\ldots$ & $\ldots$ & $\ldots$ & $\ldots$ \\
\hline Chile & 1.26 & 1.4 & $\ldots$ & 24.9 & $\ldots$ & $\ldots$ & $\ldots$ & $\ldots$ \\
\hline Colombia & $\ldots$ & 2.0 & $\ldots$ & 395.8 & $\ldots$ & $\ldots$ & $\ldots$ & $\ldots$ \\
\hline Costa Rica & 1.00 & $\ldots$ & 4.1 & 202.5 & 2019.3 & 17.3 & 2.0 & $\ldots$ \\
\hline Dominica & 5.25 & $\ldots$ & $\ldots$ & $\ldots$ & $\ldots$ & $\ldots$ & $\ldots$ & $\ldots$ \\
\hline Dominican Republic & $\ldots$ & $\ldots$ & $\ldots$ & $\ldots$ & $\ldots$ & $\ldots$ & $\ldots$ & $\ldots$ \\
\hline El Salvador & 2.23 & $\ldots$ & 5.4 & $\ldots$ & 2151.7 & 21.9 & $\ldots$ & $\ldots$ \\
\hline Guyana & 12.45 & 4.8 & $\ldots$ & 75.1 & $\ldots$ & $\ldots$ & $\ldots$ & 0.00 \\
\hline Honduras & $\ldots$ & $\ldots$ & $\ldots$ & $\ldots$ & $\ldots$ & $\ldots$ & $\ldots$ & $\ldots$ \\
\hline Jamaica & $\ldots$ & 14.8 & $\ldots$ & $\ldots$ & $\ldots$ & $\ldots$ & $\ldots$ & 0.04 \\
\hline Mexico & $\ldots$ & $\ldots$ & $\ldots$ & 635.1 & $\ldots$ & $\ldots$ & $\ldots$ & $\ldots$ \\
\hline Montserrat & 6.00 & $\ldots$ & $\ldots$ & $\ldots$ & $\ldots$ & $\ldots$ & $\ldots$ & $\ldots$ \\
\hline Netherlands Antilles & 11.00 & 100.0 & $\ldots$ & $\ldots$ & $\ldots$ & $\ldots$ & $\ldots$ & $\ldots$ \\
\hline Peru & $\ldots$ & $\ldots$ & 80.0 & $\ldots$ & 2171.9 & 21.2 & 1.1 & $\ldots$ \\
\hline Saint Kitts and Nevis & 8.00 & $\ldots$ & 2.0 & $\ldots$ & $\ldots$ & $\ldots$ & $\ldots$ & $\ldots$ \\
\hline Saint Lucia & 4.22 & $\ldots$ & 2.0 & 303.2 & 537.5 & 5.0 & 0.8 & $\ldots$ \\
\hline $\begin{array}{l}\text { Saint Vincent } \\
\text { and the Grenadines }\end{array}$ & 12.67 & 5.0 & $\ldots$ & $\ldots$ & $\ldots$ & $\ldots$ & $\ldots$ & 5.52 \\
\hline Suriname & 2.59 & $\ldots$ & 42.0 & 45.6 & 2430.2 & 4.3 & 0.9 & $\ldots$ \\
\hline Trinidad and Tobago & 2.33 & 8.7 & 39.3 & $\ldots$ & 2790.8 & 12.4 & 1.4 & $\ldots$ \\
\hline Uruguay & $\ldots$ & $\ldots$ & 4.7 & $\ldots$ & $\ldots$ & $\ldots$ & $\ldots$ & $\ldots$ \\
\hline Venezuela & $\ldots$ & 0.1 & $\ldots$ & 462.8 & $\ldots$ & $\ldots$ & $\ldots$ & 0.04 \\
\hline $\begin{array}{l}\text { Percentage of each indicator } \\
\text { Availability for all countries }\end{array}$ & $60.0 \%$ & $48.0 \%$ & $36.0 \%$ & $36.0 \%$ & $28.0 \%$ & $24.0 \%$ & $20.0 \%$ & $20.0 \%$ \\
\hline
\end{tabular}




\begin{tabular}{|c|c|c|c|c|c|c|c|c|}
\hline 己̇ & 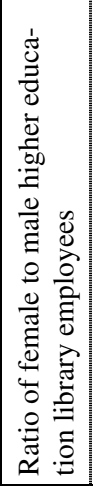 & 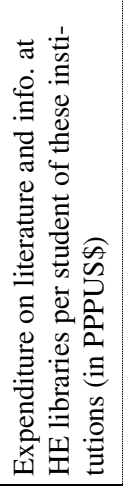 & 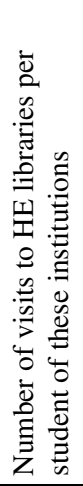 & 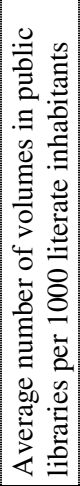 & 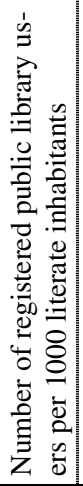 & 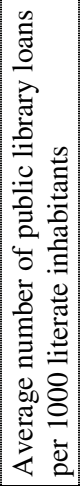 & 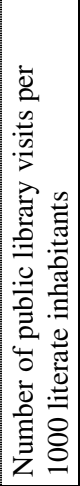 & 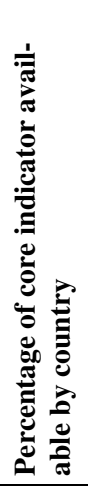 \\
\hline Antigua and Barbuda & $\ldots$ & $\ldots$ & $\ldots$ & $\ldots$ & $\ldots$ & $\ldots$ & $\ldots$ & $34.8 \%$ \\
\hline Argentina & $\ldots$ & $\ldots$ & $\ldots$ & $\ldots$ & $\ldots$ & $\ldots$ & $\ldots$ & $52.2 \%$ \\
\hline Bahamas & $\ldots$ & $\ldots$ & $\ldots$ & $\ldots$ & $\ldots$ & $\ldots$ & $\ldots$ & $60.9 \%$ \\
\hline Brazil & $\ldots$ & $\ldots$ & $\ldots$ & $\ldots$ & $\ldots$ & $\ldots$ & $\ldots$ & $21.7 \%$ \\
\hline British Virgin Islands & $\ldots$ & $\ldots$ & $\ldots$ & $\ldots$ & $\ldots$ & $\ldots$ & $\ldots$ & $21.7 \%$ \\
\hline Chile & $\ldots$ & $\ldots$ & $\ldots$ & $\ldots$ & $\ldots$ & $\ldots$ & $\ldots$ & $52.2 \%$ \\
\hline Colombia & $\ldots$ & $\ldots$ & $\ldots$ & $\ldots$ & $\ldots$ & $\ldots$ & $\ldots$ & $43.5 \%$ \\
\hline Costa Rica & $\ldots$ & 851.04 & $\ldots$ & $\ldots$ & $\ldots$ & $\ldots$ & $\ldots$ & $65.2 \%$ \\
\hline Dominica & $\ldots$ & $\ldots$ & $\ldots$ & $\ldots$ & $\ldots$ & $\ldots$ & $\ldots$ & $17.4 \%$ \\
\hline Dominican Republic & $\ldots$ & $\ldots$ & $\ldots$ & $\ldots$ & 1.5 & $\ldots$ & $\ldots$ & $21.7 \%$ \\
\hline El Salvador & 1.63 & $\ldots$ & $\ldots$ & $\ldots$ & $\ldots$ & $\ldots$ & $\ldots$ & $56.5 \%$ \\
\hline Guyana & $\ldots$ & $\ldots$ & $\ldots$ & $\ldots$ & $\ldots$ & $\ldots$ & $\ldots$ & $56.5 \%$ \\
\hline Honduras & $\ldots$ & $\ldots$ & $\ldots$ & $\ldots$ & $\ldots$ & $\ldots$ & $\ldots$ & $17.4 \%$ \\
\hline Jamaica & $\ldots$ & $\ldots$ & $\ldots$ & $\ldots$ & $\ldots$ & $\ldots$ & $\ldots$ & $47.8 \%$ \\
\hline Mexico & $\ldots$ & $\ldots$ & $\ldots$ & $\ldots$ & $\ldots$ & $\ldots$ & $\ldots$ & $43.5 \%$ \\
\hline Montserrat & $\ldots$ & $\ldots$ & $\ldots$ & $\ldots$ & $\ldots$ & $\ldots$ & $\ldots$ & $17.4 \%$ \\
\hline Netherlands Antilles & $\ldots$ & $\ldots$ & $\ldots$ & $\ldots$ & $\ldots$ & $\ldots$ & $\ldots$ & $47.8 \%$ \\
\hline Peru & 1.43 & 30.83 & 3.9 & 0.8 & $\ldots$ & $\ldots$ & $\ldots$ & $52.2 \%$ \\
\hline Saint Kitts and Nevis & 3.00 & $\ldots$ & $\ldots$ & $\ldots$ & $\ldots$ & $\ldots$ & $\ldots$ & $26.1 \%$ \\
\hline Saint Lucia & $\ldots$ & $\ldots$ & $\ldots$ & $\ldots$ & $\ldots$ & $\ldots$ & $\ldots$ & $60.9 \%$ \\
\hline $\begin{array}{l}\text { Saint Vincent } \\
\text { and the Grenadines }\end{array}$ & $\ldots$ & $\cdots$ & $\cdots$ & $\cdots$ & $\cdots$ & $\cdots$ & $\cdots$ & $47.8 \%$ \\
\hline Suriname & 7.40 & 0.32 & 1.9 & $\ldots$ & $\ldots$ & $\ldots$ & $\ldots$ & $78.3 \%$ \\
\hline Trinidad and Tobago & 1.91 & $\ldots$ & $\ldots$ & $\ldots$ & $\ldots$ & $\ldots$ & $\ldots$ & $69.6 \%$ \\
\hline Uruguay & $\ldots$ & $\ldots$ & $\ldots$ & $\ldots$ & $\ldots$ & $\ldots$ & $\ldots$ & $26.1 \%$ \\
\hline Venezuela & $\ldots$ & $\ldots$ & $\ldots$ & $\ldots$ & $\ldots$ & $\ldots$ & $\ldots$ & $52.2 \%$ \\
\hline $\begin{array}{l}\text { Percentage of each indicator } \\
\text { Availability for all countries }\end{array}$ & $20.0 \%$ & $12.0 \%$ & $8.0 \%$ & $4.0 \%$ & $4.0 \%$ & $0.0 \%$ & $0.0 \%$ & \\
\hline
\end{tabular}

